\title{
KÖPÜK HELVA ÜRETİM PARAMETRELERİNİN RENK VE YOĞUNLUK ÖZELLİKLERİNE ETKİİ: TAGUCHİ MATEMATİKSEL MODEL OPTIMIZASYONU
}

\author{
Mehmet Güldane $^{1 *}$, Mahmut Doğan ${ }^{2}$ \\ ${ }^{1}$ Sakarya Uygulamalı Bilimler Üniversitesi, Pamukova Meslek Yüksekokulu, Sakarya \\ ${ }^{2}$ Erciyes Üniversitesi, Mühendislik Fakültesi, Gıda Mühendisliği Bölümü, Kayseri
}

Geliş / Received: 08.07.2020; Kabul / Accepted: 09.11.2020; Online bask1 / Published online: 01.12.2020

Güldane, M., Doğan, M. (2020). Köpük helva üretim parametrelerinin renk ve yoğunluk özelliklerine etkisi: taguchi matematiksel model optimizasyonu. GIDA (2020) 45(6) 1248-1260 doi: 10.15237/ gida.GD20089

Güldane, M., Doğan, M. (2020). The effect of process parameters on color and density properties of foam halva: taguchi mathemetical model optimization. GID A (2020) 45(6) 1248-1260 doi: 10.15237/gida.GD20089

\section{ÖZ}

Bu çalşmada; kontrol parametrelerinin (protein çeşidi, hidrokolloid konsantrasyonu, hidrokolloid çeşidi ve çırpma sıcaklığı) model köpüklerin yoğunluklarına ve köpük helvaların renklerine etkileri Taguchi yöntemi kullanılarak belirlenmiştir. En düşük yoğunluk ve en yükssek L* değerleri için Sinyal/Gürültü oranları Taguchi $\mathrm{L}_{16}$ deney tasarımı (44) kullanılarak saptanmıştı. Analiz sonuçlarına göre; peynir altı suyu protein izolatı $(\% 0.5)$, saponin (\%0.096) ve pektin (\%0.05) çözeltisinin $80{ }^{\circ} \mathrm{C}$ 'de çırpılmasılya elde edilen model köpügün en iyi köpürebilen örnek olduğu belirlenmiştir. Ayrıca, bu örneğin yoğunluk yanıtı Sinyal/Gürültü oranının $(13.98 \mathrm{~dB})$ kontrolden $(11.49 \mathrm{~dB})$ daha yüksek olduğu tespit edilmiştir. Peynir alt suyu protein izolatı (\%0.5), saponin (\%0.096) ve ksantan gam (\%0.1) ile hazırlanan çözeltinin $40{ }^{\circ} \mathrm{C}$ 'de çırpılmasıyla üretilen model köpük helva ve geleneksel yöntemle üretilen helvanın parlaklıkları arasında istatistiksel açıdan önemli fark bulunmamıştr. Sonuç olarak; saponin içeriği azaltılmış, hedeflenen yoğunlukta ve renkte köpüklerin/köpük helvaların üretilebileceği Taguchi optimizasyon yöntemiyle belirlenmiştir.

Anahtar kelimeler: Hidrokolloidler, köpürme, saponin, Sinyal/Gürültü oranı, süt proteinleri

\section{THE EFFECT OF PROCESS PARAMETERS ON COLOR AND DENSITY PROPERTIES OF FOAM HALVA: TAGUCHI MATHEMETICAL MODEL OPTIMIZATION}

\begin{abstract}
In this study, effects of control parameters (protein type, hydrocolloid concentration, hydrocolloid type and mixing temperature) on density response of model foams and color response of model foam halvas. Signal/Noise ratio for the lowest density and the highest $\mathrm{L}^{*}$ values were obtained using Taguchi $\mathrm{L}_{16}$ experimental design $\left(4^{4}\right)$. As a result of the analysis, model foam obtained by mixing solution containing whey protein isolate $(0.5 \%)$, saponin $(0.096 \%)$ and pectin $(0.05 \%)$ at $80{ }^{\circ} \mathrm{C}$ was determined as the best foaming sample. For density response, Signal/Noise ratio of this sample $(13.98 \mathrm{~dB})$ was also detected higher than control (11.49 dB). There was no significant difference
\end{abstract}

\footnotetext{
${ }^{*}$ Yazışmalardan sorumlu yazar / Corresponding author;

$\triangle$ mehmetguldane@subu.edu.tr

(2) (+90) 2646160800

冝 $(+90) 2646160014$
}

Mehmet Güldane; ORCID no: 0000-0001-7321-0496

Mahmut Doğan; ORCID no: 0000-0003-1639-4641 
between the model foam halva produced by whipping the solution (whey protein isolate $(0.5 \%)$, saponin $(0.096 \%)$ and xanthan gam $(0.1 \%))$ at $40^{\circ} \mathrm{C}$ and traditional method. Consequently, it was determined that model foams/foam halvas with reduced saponin content and targeted density and color could be produced using Taguchi method.

Keywords: Hydrocolloids, foaming, saponin, Signal/Noise ratio, milk proteins

\section{GİRIŞ̧}

Sürekli bir sıvı faz içerisinde dağılmış halde bulunan değişik boyuttaki gaz baloncuklarının varlı̆g1 köpük adı verilen termodinamik olarak stabil olmayan sistemi açiklanmaktadır. Klasik anlamda köpükler; protein, saponin ya da sodyum dodesil sülfat gibi yüzey aktif özellik gösteren maddeleri içeren sıvı karışımların çırpılması veya püskürtülmesiyle elde edilmektedir (Campbell ve Mougeot, 1999; Foegeding vd., 2006; Lazidis vd., 2014). Çırpma veya köpükleştirme işlemiyle katı veya yarı katı matriks içinde (sürekli faz) bir gaz fazın küçük baloncuklar şeklinde dağılması sağlanarak gıda materyaline havalandırılmış bir yapı kazandırılmaktadır.

Köpük sistemlerinin özellikleri yüzey aktif maddeye bağlı olarak değişkenlik göstermektedir. Gıda sanayinde köpük elde etmek amacıyla en çok kullanılan arayüzey stabilizatörü proteinlerdir (Abascal ve Gracia-Fadrique, 2009; Lau ve Dickinson, 2005). Yumurta akı proteinleri en çok tercih edilen köpürtme elemanlarıdır. Son yıllarda, bu proteinlerin yerine kullanilabilecek alternatif kaynaklarının belirlenmesine yönelik çalışmalar hızlanmıştır. $\mathrm{Bu}$ amaçla süt proteinlerinin geleneksel gida ürünlerinden köpük helvada kullanılabilirliğinin araşturılması hedeflenmiştir.

Peynir endüstrisinde bir yan ürün olan peynir altı suyunun (PS) yapisinda su, laktoz, protein, tuz ve süt yağ1 bulunmaktadır. Bu değerli atıklardan protein dışı unsurların çeşitli filtrasyon teknikleri (ultrafiltrasyon, diafiltrasyon, vb.) kullanilarak uzaklaştırılmasıyla ticari PS protein tozları üretilmektedir. Sıcaklığa duyarlı olan PS proteinlerinin köpürme özelliklerinden, bileşiminde en çok bulunan $(>\% 50), \quad \beta$ laktoglobulinin ( $\mathrm{pI}=4.7-5.1)$ sorumlu olduğu bildirilmiştir (Albano vd., 2019).

Asit kazeinin alkalide çözündürülmesiyle üretilen sodyum kazeinat (Na-KAZ), suda çözünebilmekte ve esnek yapısıyla hava/sıv1 yüzeylerde kolaylikla konumlanabilmektedir. Asidik koşullarda ve/veya tuzların varlığında bu proteinin köpük özellikleri olumsuz etkilenmektedir (Abd El-Salam ve El-Shibiny, 2020).

Ülkemizde bazı g1da ürünlerinin köpürtülerek yapısına hava katılmasında çöven bitkisinden (Gypsophila spp.) elde edilen çöven suyu kullanılmaktadır. Çöven suyunun yapisında şekerler, reçineler ve saponin bulunmaktadır (Battal vd., 2003). Çöven suyunda çok fazla sayıda iyonik/iyonik olmayan saponin tespit edilmiştir (Ulaganathan vd., 2019). Saponinlerin hava/siv1 arayüzeyinde etkin olmasını sağlayan temel unsur hidrofobik aglikon ve hidrofilik şeker gruplarını içermesidir (Böttcher vd., 2016). Saponinlerin en önemli özelliklerinden birisi sulu çözeltilerinde nisbeten stabil ve sabun benzeri köpük vermeleridir (Çelik vd., 2007).

Geleneksel tatllarımızdan olan köpük helva üretiminde de çöven suyu kullanılmaktadır. Yüksek sıcaklıklarda $\left(>100{ }^{\circ} \mathrm{C}\right)$ belirli bir kivama ulaşıncaya kadar kaynatılan şeker şurubu sitrik asit ilavesiyle asitlendirilmektedir. Vakum işlemi uygulanarak soğutulan şuruba çöven suyu ilave edilmektedir. Şeker şurubu/çöven suyu karışımı paletler kullanılarak karıştırılarak geleneksel köpük helva üretilmektedir (Sarıçoban ve Sarıkaya, 2004). Bu helvanın üretiminde çöven suyu ile birlikte yumurta akının da kullanıldığ bilinmektedir. Saponinler ve proteinler arasındaki etkileşimlerin proteinlerin 1 sıl direncini artırdığı ve yüzey/arayüzey özelliklerini iyileştirdiği bildirilmiştir (Guclu-Ustundag ve Mazza, 2007). Türk Gıda Kodeksi Tahin Helvası Tebliğine göre (Tebliğ No:2015/28); tahin helvasinda \%0.1'den çok saponin bulunmasına izin verilmemektedir (Anonim, 2015). Bunun nedeni, saponinin $70 \mathrm{~kg}$ ağırlığındaki bir yetişkinin vücuduna 0.7 gramdan fazla alınmasi durumunda toksik etkilerinin bulunmasıdır (Çam ve Topuz, 2018). 
Yapısal olarak yüksek kalitede köpük üretiminde süt proteinlerinin kullanılabileceği çeşitli çalışmalarla gösterilmiştir. Fakat bu proteinler köpük eldesinde tek başlarına kullanıldıklarında arzulanan özelliklerde köpük yapisı üretilememektedir. Bundan dolay1, süt proteinlerinin hidrokolloidlerle birlikte kullanılması önerilmektedir (Narchi vd., 2009).

Suda çözündügünde jel oluşturabilen veya düşük konsantrasyonlarda kıvamlı çözeltiler oluşturan yüksek molekül ağırlığındaki sakkaritler hidrokolloidler olarak sinıflandırlmaktadır. Çok fazla çeşidi olan zamklı yapıdaki maddelerden bitki ve mikrobiyal polisakkaritler ile bunlann türevleri gıda sanayinde kullanılmaktadır (Sadahira vd., 2014). Gamlar, genel olarak, yüzey aktif özellikte olmadıklarından hava/su arayüzeyine konumlanma eğiliminde değildirler (Neves vd., 2018).

Protein ve iyonik polisakkaritlerin etkileşimde olduğu siv1 sistemlerde, bir proteinin izoelektrik noktasının (pI) çözelti pH'sından farklı olması biyopolimerler arasındaki etkileşimlerin derecesini belirlemektedir. Gıda proteinlerinin çoğu $\left(\mathrm{pI}_{\text {protein }} \sim 5.0\right)$ iyonik polisakkartilerle (pKa polisakkarit 23.0$)$ her iki polimerin de zit yüklü olduğu $\mathrm{pH}$ aralığında $\left(\mathrm{pI}_{\text {protein }}<\mathrm{pH}<\mathrm{pK} a_{\text {polisakkarit }}\right.$ ) elektrostatik etkileşime girerek çözünür/çözünmez bileşikler oluşturmaktadırlar (Dickinson, 1998).

Genellikle nötr koşullara yakın $\mathrm{pH}$ değerlerinde ( $\mathrm{pH}=6-7$ ) yapılan çalışmalarda; peynir altı protein konsantresi (PASP-K) ve ksantan gam (protein:polisakkarit $=(10-25):(0.05-0.15)$

(Martínez-Padilla vd., 2015), yumurta ak1 (\%0.05) ve pektin/guar gam (protein:polisakkarit $=5:(5 ; 0.05 ; 0.1)$ ) (Ibanoglu ve Erçelebi, 2007), PASP-K ve ksantan gam/karragenan (protein:gam=4:1) (LiszkaSkoczylas vd., 2014), peynir alt suyu protein izolat (PASP-I) ve ksantan gam (protein:gam=20:1) (Narchi vd., 2009), polisakkaritlerin köpürmeyi engelleyerek/ geciktirerek köpük yoğunluklarının artmasına neden oldukları belirlenmiştir. Tersine, $\mathrm{pH}=4$ 'de yapılan çalışmalarda, $\beta$-laktaglobulin ve pektin arasindaki elektrostatik etkileşimler sonucunda oluşan çözünür bileşenlerin köpük özelliklerini iyileştirdiği görülmüştür (Ganzevles vd., 2006; Girard vd., 2003).

Taguchi tekniği, en az saylda veriyle optimizasyon imkanı sağlayan eşsiz ve güçlü bir metottur. Bu yöntem kullanılarak deney tasarım maliyetleri azaltılmakta, kalite artırılmakta ve sağlam tasarım çözümleri sunulmaktadır (Ravanfar vd., 2015). Optimum koşulların tahminlenmesinde yararlanılan bu yöntem, hedeflenen üretim parametrelerini etkileyen zayif unsurların da belirlenmesinde kullanılabilmektedir (Mekonnen vd., 2015). Taguchi yönteminde güçlü bir tasarımda faydalanılan en önemli unsurlar Sinyal/Gürültü (S/N) oranı ve tasanı dizisidir. Deney tasarım1, ürün özelliklerini etkileyen faktörleri aynı deney şablonunda değerlendirirken; $\mathrm{S} / \mathrm{N}$ oran1, ürün kalitesini bu faktörleri temel alarak ölçmektedir. Yüksek $\mathrm{S} / \mathrm{N}$ oranı yüksek kaliteli ürünü temsil etmektedir (Roy, 2010).

Bu çalışmada; geleneksel yöntemle üretilen köpük helvadaki çöven suyu miktarının azaltılması ve süt proteini çeşitleri (peynir altı suyu protein konsantresi (PASP-K), peynir altı suyu protein izolatı (PASP-İ), sodyum kazeinat (Na-KAZ) ve demineralize peynir altı suyu proteinleri (DPASP)), hidrokolloid konsantrasyonu (\%0.05, $\% 0.1, \% 0.15$ ve $\% 0.2)$, hidrokolloid çeşitleri (keçiboynuzu gam (KG), karragenan, pektin, ksantan gam) ve çırpma sicaklı̆̆ının $\left(40^{\circ} \mathrm{C}, 60^{\circ} \mathrm{C}\right.$, $80{ }^{\circ} \mathrm{C}$ ve $100{ }^{\circ} \mathrm{C}$ ) üretim faktörleri olarak kullanıldığı Taguchi optimizasyon yöntemiyle en düşük yoğunluktaki model köpük örneği ve en parlak renge sahip model köpük helvanın üretilmesi için gerekli proses faktör seviyelerinin belirlenmesi amaçlanmıştır.

\section{MATERYAL VE YÖNTEM}

\section{Materyal}

Ticari protein tozlarından PASP-K (\%80 protein, $\% 5.5$ yağ, \%14 laktoz, \%4 mineral madde, $\% 5$ nem) ve PASP-İ (\%92 protein, $\% 1$ yağ, $\% 3$ laktoz, $\% 5$ mineral madde, \%5 nem) (Laktalis, Fransa), D-PASP (\%7.9 protein, $\% 0.67$ yağ, \%86 laktoz, $\% 4.3$ mineral madde, \%1.47 nem) (Maybi, Türkiye) ve Na-KAZ (\%86.5 protein, $\% 2$ yă̆, 
$\% 0.3$ laktoz, $\% 4.5$ mineral madde, $\% 5.5$ nem) (Alfasol, Türkiye)'den tedarik edilmiştir. Ticari çöven suyu (\%6.4 saponin, \%13 suda çözünür kuru madde, $\% 9$ mineral madde ve $\% 87$ nem), keçiboynuzu gamı, karragenan, pektin, ksantan gam, sitrik asit ve sodyum karbonat (Tito, Türkiye)'den ve şeker (Torku A.Ş., Türkiye) yerel bir marketten temin edilmiştir. Kullanılan diğer kimyasallar analitik standartta olup Sigma (Sigma Chemical Company, MO, ABD) ve Merck (Merck KGaA, Darmstadt, Almanya) firmalarından temin edilmiştir.

\section{YÖNTEM}

Protein ve hidrokolloid çözeltilerinin hazırlanmasi: PASP-K, PASP-İ ve D-PASP tozlanna distile su, Na-KAZ üzerine fosfat tamponu ( $\mathrm{pH}$ 7.4) ilave edilerek manyetik karıştrirıyla (Stuart, CC 162, İngiltere) 2 saat süresince 1500 rpm'de karıştırlarak \%10'luk çözeltiler hazırlanmıştır. $\mathrm{Bu}$ çözeltiler, polimerlerin tamamen çözünmesi için bir gece boyunca buzdolabinda $+4{ }^{\circ} \mathrm{C}$ 'de bekletilerek kullanılmadan önce oda sıcaklığına getirilmiştir (Shen vd., 2017).

Hidrokolloid çözeltileri (\%1) uygun sıcaklıktaki distile su ilavesiyle 10 dakika 300 rpm'de ardından 200 rpm'de 2 saat süresince karıştrılmış ve tamamen çözünmeleri için oda koşullarında bekletilmiştir.

Şeker şurubunun hazırlanması: $2 \mathrm{~kg}$ toz şeker ve $500 \mathrm{ml}$ distile su karıştırrldıktan sonra mikser (KM070, Kenwood, İngiltere) ile 30 dakika süresince 1sıtıllp kaynatılarak asitlendirilmiş ve tamamen çözündürülerek oBriks değeri refraktometreyle (Reichert AR700, ABD) 85'e ayarlanmıştur. Şeker şurubu $60{ }^{\circ} C^{\prime}$ 'nin altına soğutulduktan sonra köpüklerin/köpük helvaların üretiminde kullanılmıştır.

Köpük helva üretiminde kullanılacak sıvı karışımın hazırlanması: Köpük model formülasyonunun belirlenmesinde köpük helva üretimi yapan bir firmadan (Çamlica Helva, Kütahya) temin edilen üretim reçetesi kullanılmıştır. Üretimde kullanılacak şeker tipi, şeker briksi, çöven suyu miktarı, mikser başlığ1 ve hızı, protein tipi ve miktarının seçilmesinde literatür verilerine dayanılarak yapılan ön deneme sonuçlarından yararlanılmıştur.

Beherin (250 ml, İsolab) içerisine Çizelge 2'ye göre sırasıyla çöven suyu ( $3 \mathrm{ml}), \% 10$ 'luk protein çözeltisi ve gerekli miktarda hidrokolloid ilave edilerek 15 dakika süresince manyetik karıştırıcıda (Stuart, CC 162, İngiltere) 200 rpm'de karışması sağlanmıştır. Toplam çözelti ağırllı̆ı 200 gram oluncaya kadar şeker şurubu $\left(<60 \quad{ }^{\circ} \mathrm{C}\right)$ ilave edilerek karıştırılmaya 10 dakika daha devam edilmiştir. $\mathrm{Bu}$ işlemden sonra sitrik asit (\%5) kullanılarak karışımın $\mathrm{pH}$ değeri $\mathrm{pH}$ metre ile (WTW, İnolab, Almanya) 4'e, briks değeri refraktometre (Reichert AR700, ABD) ile 70'e ayarlanmışur.

Kontrol örneğinin üretilmesinde sadece çöven suyu $(6 \mathrm{ml})$ ve şeker şurubu (70 briks, $\mathrm{pH} 4$ ) kullanılmıştır.

Köpük helvaların üretilmesi: Briks ve $\mathrm{pH}$ ayarlamaları tamamlanan siv1 karışımlar mikser kabına (6.7 L) aktarılmıstır. Bu çözeltiler, Çizelge 2'deki Taguchi tasarım verilerine uygun şekilde 1s1tma kontrollü mikser (KM070, Kenwood, İngiltere) ile mikser ucu olarak "statik K mikser" kullanılarak ve çırpıcı hızı 158 rpm'e ayarlanarak 15 dakika süresince çırpılmıştur. Kontrol örneğinin üretilmesinde çırpma sıcaklığ $100{ }^{\circ} \mathrm{C}$ seçilmiştir. Süre sonunda örneklerin yoğunluk analizleri yapilarak, mikserin isitma fonksiyonu sonlandırılıp, çırpma işlemine devam edilmiştir. Köpüklerin yoğunlukları $0.5 \mathrm{~g} / \mathrm{cm}^{3} \mathrm{e}$ ulaştı̆̆ında çırpma işlemi sonlandırılarak örneklerin renk ( $\left.\mathrm{L}^{*}\right)$ değerleri belirlenmiştir

Model köpüklerde yoğunluk özelliklerinin belirlenmesi: Çırpma işlemi sonlandırıldıktan hemen sonra çırpma aparatı dikkatlice kaldırılmış ve model köpük örnekleri plastik spatula ile ön tartımı alınmış belirli hacimdeki petri kabına (90mmx $17 \mathrm{~mm}$, İsolab) doldurulmuştur. Petri kutusunun yüzeyi spatulayla seviyelendirilip tartımlar alınmıştır. $\mathrm{Bu}$ işlem toplamda iki dakikayla sınırlandırılmıstır. Örneklerin yoğunluk (Eşitlik 1) değerleri belirlenmiştir (Lau ve Dickinson, 2005; Martínez-Padilla vd., 2015 ). 


$$
\begin{aligned}
& \text { yoğunluk }\left(g / \mathrm{cm}^{3}\right) \\
& x \mathrm{ml} k \text { öpük ă̆ } \iota r l ı \breve{g} l \\
& =\overline{\text { silindirik kabın } \times \mathrm{ml}^{\prime} \operatorname{sinin} \text { hacmi }}
\end{aligned}
$$

Model köpük helvalarda renk özelliklerinin belirlenmesi: Model köpüklerin $0.5 \mathrm{~g} / \mathrm{cm}^{3}$ yoğunluk değerine ulaşıncaya kadar çırpılmasıyla üretilen model köpük helvalar renk ölçüm cihazının (Konica Minolta CR-5, Japan) cam ölçü kabına plastik spatula ile bask1 uygulamadan doldurulmuş ve kalibre edilmiş cihazda örneklerin L* (açıklık-koyuluk) değerleri belirlenmiştir.

Deneysel tasarım: $\mathrm{Bu}$ çalışmada arzulanan köpük özelliklerinin optimizasyonu amaciyla Taguchi yöntemi kullanılmıştır. Model parametrelerinin belirlenmesinde aşağıdaki aşamalar uygulanmıştır (Roy, 2010).

1. Köpük helva üretiminde önemli kontrol parametreleri ve seviyeleri ile optimize edilmesi istenen unsurlarin (yanttlar) belirlenmesi,

2. Uygun deney tasarımının belirlenerek analizlerin dizideki sıraya göre gerçekleştirilmesi,
3. Deneysel verilerin $\mathrm{S} / \mathrm{N}$ oranı ve ANOVA testi kullanilarak analiz edilmesi,

4. Kontrol faktörlerinin en ideal seviyelerinin belirlenmesi,

5. Doğrulama deneyleri ile optimum seviyelerin kontrol edilmesi.

Köpük helvalarda, daha açı görünümdeki g1da köpükleri parlak renkleriyle tercih edilmektedir. Ayrica, endüstriyel uygulamalarda yapisına daha fazla miktarda hava katabilme kabiliyetindeki köpükler istenmektedir.

$\mathrm{Bu}$ çalışmada; protein çeşidi, hidrokolloid konsantrasyonu, hidrokolloid çeşidi ve çırpma s1caklı̆g kontrol faktörleri olarak belirlenmiştir (Çizelge 1). Her bir faktörün ürün özelliklerine etkisi dört farklı seviyede test edilmiştir. Faktör ve seviyelerin köpük özelliklerine etkilerini belirlemek amacıyla ikişer tekrarlı 32 deney yapılmıstur. $\mathrm{Bu}$ deneylerde $\mathrm{L}_{16}$ deney tasarımı kullanılmıştır (Çizelge 2).

\begin{tabular}{|c|c|c|c|c|c|}
\hline $\begin{array}{l}\text { Faktörler } \\
\text { Factors }\end{array}$ & $\begin{array}{l}\text { Sembol } \\
\text { Symbol }\end{array}$ & $\begin{array}{l}\text { Seviye } 1 \\
\text { Level } 1\end{array}$ & $\begin{array}{l}\text { Seviye } 2 \\
\text { Level } 2\end{array}$ & $\begin{array}{l}\text { Seviye } 3 \\
\text { Level } 3\end{array}$ & $\begin{array}{l}\text { Seviye } 4 \\
\text { Level } 4\end{array}$ \\
\hline $\begin{array}{l}\text { Protein çeşidi } \\
\text { Protein type }\end{array}$ & A & $\begin{array}{l}\text { PASP-K } \\
W P C\end{array}$ & $\begin{array}{c}\text { PASP-İ } \\
W P I\end{array}$ & $\begin{array}{c}\mathrm{Na}- \\
\mathrm{KAZ} \\
\mathrm{Na}-\mathrm{C} A S \\
\end{array}$ & $\begin{array}{c}\text { D-PASP } \\
D-W P\end{array}$ \\
\hline $\begin{array}{l}\text { Hidrokolloid } \\
\text { konsantrasyonu(\%) } \\
\text { Hydrocolloid concentration(\%) }\end{array}$ & B & 0.05 & 0.1 & 0.15 & 0.20 \\
\hline $\begin{array}{l}\text { Hidrokolloid çeşidi } \\
\text { Hydrocolloid type }\end{array}$ & C & $\begin{array}{c}\text { Keçiboynuzu } \\
\text { gamı (KG) } \\
\text { Locust bean gum } \\
\text { (LBG) }\end{array}$ & $\begin{array}{l}\text { Karragenan } \\
\text { Carrageenan }\end{array}$ & $\begin{array}{l}\text { Pektin } \\
\text { Pectin }\end{array}$ & $\begin{array}{l}\text { Ksantan } \\
\text { Xanthan }\end{array}$ \\
\hline $\begin{array}{l}\text { Çırpma sicaklı̆̆1 }\left({ }^{\circ} \mathrm{C}\right) \\
\text { Mixing temperature }\left({ }^{\circ} \mathrm{C}\right)\end{array}$ & $\mathrm{D}$ & 40 & 60 & 80 & 100 \\
\hline
\end{tabular}

Çizelge 1. Deneysel tasarım için kontrol faktörleri ve seviyeleri

Table 1. Control factors and levels for experimental design 
Çizelge 2. Model köpüklerde/köpük helvalarda yoğunluk ve renk yanıtları deney sonuçları ve S/N değerleri

Table 2. Experimental results and $S / N$ values of density and colour responses in model foams/foam halvas

\begin{tabular}{|c|c|c|c|c|c|c|c|c|c|c|}
\hline \multirow{2}{*}{$\begin{array}{c}\text { Deney } \\
\text { No } \\
\text { Experiment } \\
\text { No }\end{array}$} & \multicolumn{4}{|c|}{$\begin{array}{c}\text { Faktörler } \\
\text { Factors }\end{array}$} & & \multicolumn{5}{|c|}{$\begin{array}{l}\text { Yanitlar } \\
\text { Responses }\end{array}$} \\
\hline & A & B & $\mathrm{C}$ & $\mathrm{D}$ & $\begin{array}{c}\text { Yoğunluk } \\
\mathrm{g} / \mathrm{cm}^{3} \\
\text { Density } \\
\mathrm{g} / \mathrm{cm}^{3}\end{array}$ & $\begin{array}{c}\text { Yoğunluk } \\
\mathrm{g} / \mathrm{cm}^{3} \\
\text { Density } \\
\mathrm{g} / \mathrm{cm}^{3}\end{array}$ & $\begin{array}{c}\mathrm{S} / \mathrm{N} \\
\text { değerleri } \\
S / N \\
\text { values }\end{array}$ & $\begin{array}{c}\text { Renk } \\
\text { L* }^{*} \\
\text { Colour } \\
\text { L* }^{*}\end{array}$ & $\begin{array}{c}\text { Renk } \\
\text { L* }^{*} \\
\text { Colour } \\
\text { L* }^{*}\end{array}$ & $\begin{array}{c}\mathrm{S} / \mathrm{N} \\
\text { değerleri } \\
S / N \\
\text { values }\end{array}$ \\
\hline 1 & 1 & 1 & 1 & 1 & 0.23 & 0.25 & 12.32 & 91.43 & 91.41 & 39.22 \\
\hline 2 & 1 & 2 & 2 & 2 & 0.27 & 0.24 & 11.83 & 91.41 & 91.41 & 39.21 \\
\hline 3 & 1 & 3 & 3 & 3 & 0.23 & 0.22 & 12.97 & 91.41 & 91.41 & 39.21 \\
\hline 4 & 1 & 4 & 4 & 4 & 0.37 & 0.36 & 8.79 & 91.37 & 91.37 & 39.21 \\
\hline 5 & 2 & 1 & 2 & 3 & 0.21 & 0.23 & 13.07 & 91.48 & 91.47 & 39.22 \\
\hline 6 & 2 & 2 & 1 & 4 & 0.26 & 0.24 & 11.97 & 91.45 & 91.44 & 39.22 \\
\hline 7 & 2 & 3 & 4 & 1 & 0.30 & 0.27 & 10.94 & 91.31 & 91.29 & 39.20 \\
\hline 8 & 2 & 4 & 3 & 2 & 0.26 & 0.23 & 12.20 & 91.41 & 91.41 & 39.21 \\
\hline 9 & 3 & 1 & 3 & 4 & 0.38 & 0.40 & 8.09 & 90.90 & 90.89 & 39.17 \\
\hline 10 & 3 & 2 & 4 & 3 & 0.38 & 0.40 & 8.12 & 91.39 & 91.40 & 39.21 \\
\hline 11 & 3 & 3 & 1 & 2 & 0.66 & 0.66 & 3.58 & 90.76 & 90.85 & 39.16 \\
\hline 12 & 3 & 4 & 2 & 1 & 0.86 & 0.86 & 1.31 & 91.54 & 91.35 & 39.22 \\
\hline 13 & 4 & 1 & 4 & 2 & 0.92 & 0.91 & 0.78 & 89.04 & 89.35 & 39.00 \\
\hline 14 & 4 & 2 & 3 & 1 & 0.89 & 0.89 & 1.00 & 89.30 & 89.35 & 39.01 \\
\hline 15 & 4 & 3 & 2 & 4 & 0.69 & 0.69 & 3.21 & 88.34 & 88.36 & 38.92 \\
\hline 16 & 4 & 4 & 1 & 3 & 0.67 & 0.67 & 3.44 & 88.14 & 88.15 & 38.90 \\
\hline
\end{tabular}

Deney sonuçlarının değerlendirilmesinde $\mathrm{S} / \mathrm{N}$ oranları dikkate alınmışır. Sinyal (S) hedeflenen nitelikleri temsil etmekte iken Gürültü $(\mathrm{N})$ deney sonuçlarını olumsuz etkileyen unsurları göstermektedir. S/N oranı; "En büyük-en iyi", "Nominal-en iyi" ve "En küçük-en iyi" olmak üzere üç kategoride değerlendirilmektedir (Roy, 2010). Model köpüklerin yoğunluklarının optimizasyonunda "En küçük-en iyi” (Eşitlik 3), model köpük helvaların renk özelliklerinin optimizasyonunda ise "En büyük-en iyi”" (Eşitlik 2) kullanılmıştır.

"En büyük-en iyi":

$S / N=-10 \log \left[\frac{1}{n} \sum_{i=1}^{n} \frac{1}{y_{i}{ }^{2}}\right]$

"En küçük-en iyi”

$S / N=-10 \log \left[\frac{1}{n} \sum_{i=1}^{n} y_{i}{ }^{2}\right]$
Burada; $y_{i}$ deneylerden elde edilen verileri, $\mathrm{n}$ ise deney sırasını göstermektedir (Silva vd., 2014).

Model köpüklerin yoğunlukları ve model köpük helvaların renkleri üzerinde etkili olan faktörlerin katkı oranını belirlemek amaciyla varyans analizi (ANOVA) verilerinden yararlanılmıştır. Taguchi yöntemiyle üretim faktörlerinin yoğunluk ve renk yantları üzerine etki düzeyleri belirlenirken varyans analizi ile kontrol faktörlerinin optimize edilen özelliğe (yoğunluk ve renk) katkı oranları bulunmuştur (Özakın ve Kaya, 2020).

İstatistiksel analiz: Deneysel verilerin analizinde Minitab yazılımı (versiyon 19.0, ABD) kullanılmıştır. Model köpüklerin ve köpük helvaların üretiminde kontrol parametrelerinin yanitlar üzerine etkileri varyans analizi (ANOVA) uygulanarak test edilmiştir. Optimum koşullarda üretilen köpük/köpük helva ile geleneksel yöntemle üretilen kontrol örneği yoğunluk ve renk yanitları $\mathrm{S} / \mathrm{N}$ oranları arasındaki istatistiki farkın saptanmasında Tukey testi kullanılmıştır. Veriler \%95 güven aralı̆̆ında değerlendirilmiştir. 


\section{SONUÇLAR VE TARTIŞMA}

Model köpüklerde yoğunluk yanıtının optimizasyonu: Model köpüklerin yoğunluk ölçüm sonuçları ve $\mathrm{S} / \mathrm{N}$ değerleri Çizelge 2'de verilmiştir. Düşük yoğunluktaki köpüklerin hedeflendiği bu çalışmada yoğunluk yanıtına ait $\mathrm{S} / \mathrm{N}$ oranlarınin $0.78 \mathrm{~dB}$ ile $13.07 \mathrm{~dB}$ arasinda değiştiği görülmektedir. Model köpüklerin yoğunluklarında en belirleyici faktörler protein çeşidi (A) ve çırpma sıcaklığ $\quad$ (D) olarak belirlenmiştir. Köpük formülasyonunda kullanılan gam konsantrasyonunun (B) model ürünün yoğunluğuna etkisi en düşük bulunmuştur (Çizelge 3). Model köpüklerde en yüksek S/N değerine sahip faktör seviyeleri optimum seviye olarak kabul edilmektedir. \%0.5 PASP-İ, \%0.096 saponin ve $\% 0.05$ pektin içeren sıvı karışımın 80 'C'de 15 dakika çırpılması sonucunda en düşük yoğunluk değerine sahip köpük örneğinin üretilebileceği görülmektedir $\left(\mathrm{A}_{2} \mathrm{~B}_{1} \mathrm{C}_{3} \mathrm{D}_{3}\right)$ (Çizelge 3). Optimum koşullarda üretilen köpük örneğinin görüntüsü Şekil 1a'da verilmiştir.

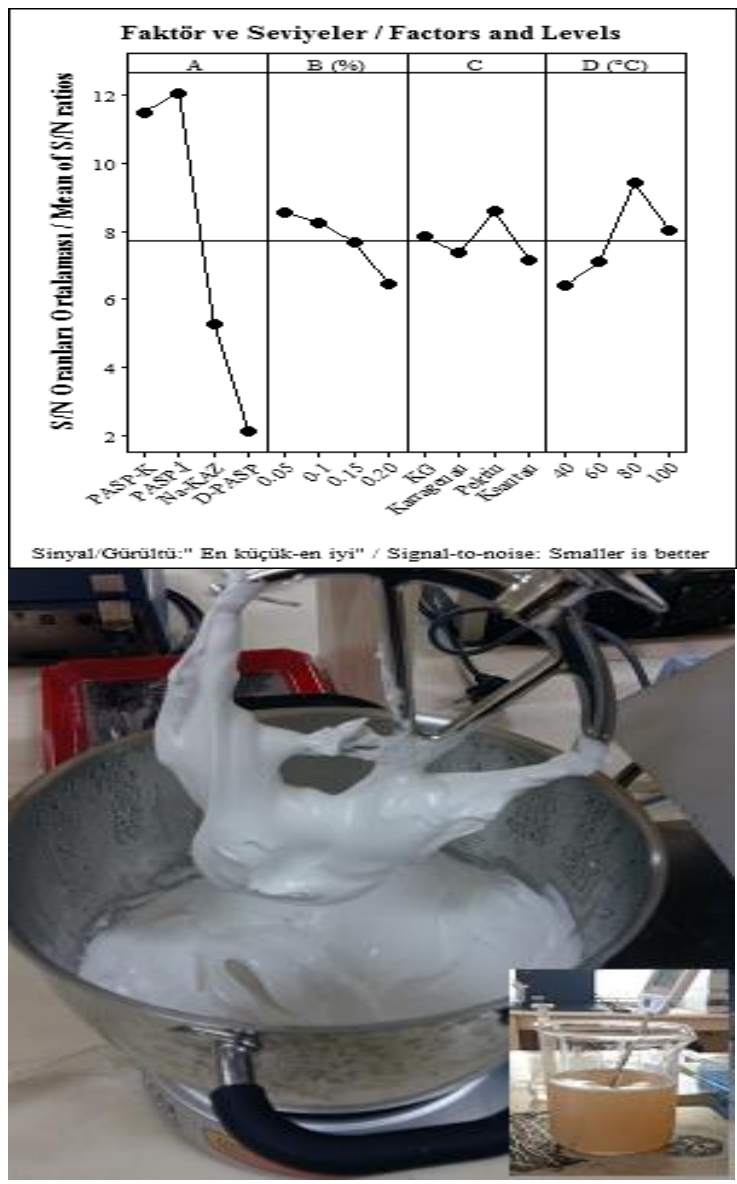

a

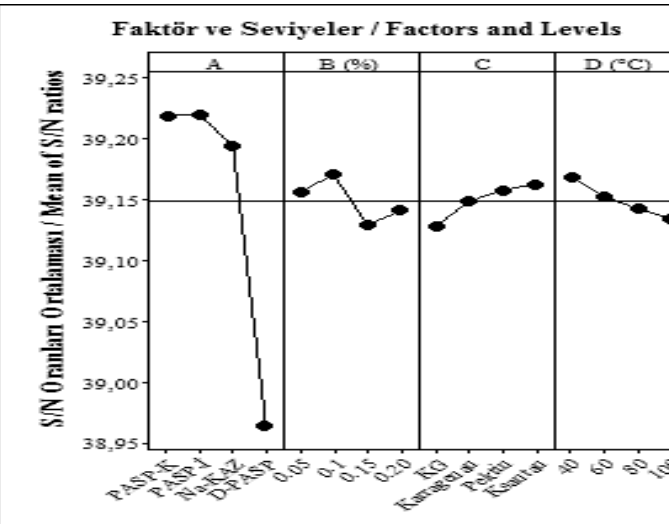

Sinyal/Gürültü:" En büyüb-en iyi" / Signa1-to-noise: Larger is better

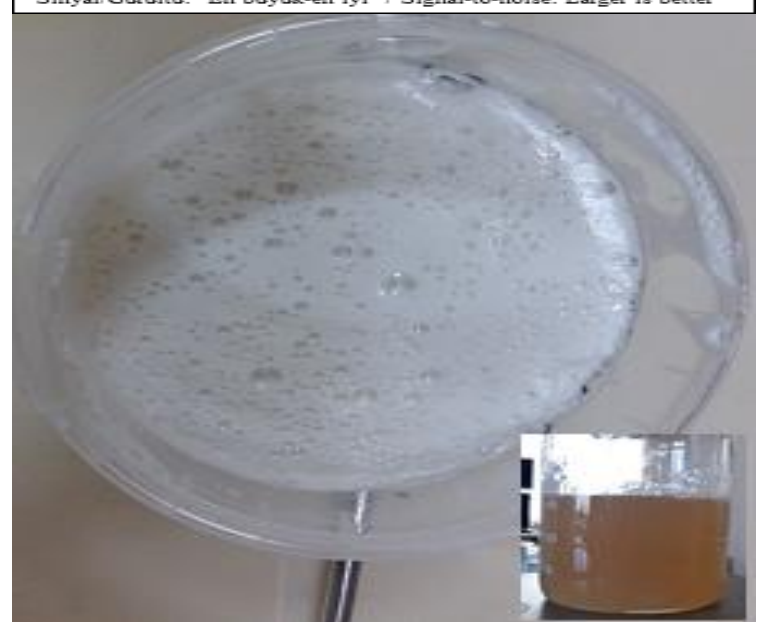

b

Şekil 1a. Model köpüklerde yoğunluk yanttları S/N oranı grafiği ve model köpük görüntüsü Şekil 1b. Model köpük helvalarda renk yanıtları $\mathrm{S} / \mathrm{N}$ oranları grafiği ve model köpük görüntüsü (A = Protein çeşidi, B (\%)= Hidrokolloid konsantrasyonu, $\mathrm{C}=$ Hidrokolloid çeşidi, $\mathrm{D}\left({ }^{\circ} \mathrm{C}\right)=$ Çırpma sıcakllğı); PASP-K= Peynir alt suyu protein konsantresi, PASP-İ= Peynir alt suyu protein izolatt, Na-KAZ= Sodyum kazeinat, D-PASP = Demineralize peynir altı suyu, $\mathrm{KG}=$ Keçiboynuzu gamı)

Figure 1a. S/N ratio graph for density responses in model foams and model foam image

Figure 1b.S/N ratio graph for colour responses in model foam halvas and model foam halva image $\left(A=\right.$ Protein type, $B(\%)=H y d r o c o l l o i d ~ c o n c e n t r a t i o n, C=H y d r o c o l l o i d ~ t y p e, ~ D\left({ }^{\circ} C\right)=$ Mixing temperature, $P A S P-K=$ Whey protein concentrate, $P A S P-\dot{I}=$ Whey protein isolate, $N a-K A Z=$ Sodium caseinate, $D-P A S P=$ Demineralized whey, $K G=$ Locust bean gum) 
Çizelge 3. Model köpüklerde/köpük helvalarda yoğunluk ve renk yanıtları S/N oranları tablosu Table 3. S/N ratio table for density and colour responses in model foams/foam balvas

\begin{tabular}{|c|c|c|c|c|c|c|c|c|}
\hline \multirow{2}{*}{$\begin{array}{l}\text { Seviye } \\
\text { Level }\end{array}$} & \multicolumn{4}{|c|}{$\begin{array}{c}\text { Yoğunluk } \\
\text { Density }\end{array}$} & \multicolumn{4}{|c|}{$\begin{array}{l}\text { Renk } \\
\text { Colour }\end{array}$} \\
\hline & A & $\mathrm{B}$ & $\mathrm{C}$ & $\mathrm{D}$ & $\mathrm{A}$ & B & $\mathrm{C}$ & $\mathrm{D}$ \\
\hline 1 & 11.48 & $8.56^{*}$ & 7.83 & 6.39 & 39.22 & 39.16 & 39.13 & $39.17^{*}$ \\
\hline 2 & $12.05^{*}$ & 8.23 & 7.36 & 7.11 & $39.23 *$ & $39.17 *$ & 39.15 & 39.15 \\
\hline 3 & 5.28 & 7.68 & $8.57 *$ & $9.41 *$ & 39,19 & 39.13 & $39.16^{*}$ & 39.14 \\
\hline 4 & 2.11 & 6.44 & 7.16 & 8.02 & 38,96 & 39.14 & 39.17 & 39.13 \\
\hline $\begin{array}{l}\text { Fark } \\
\text { Delta }\end{array}$ & 9.94 & 2.13 & 1.41 & 3.01 & 0.26 & 0.04 & 0.04 & 0,03 \\
\hline $\begin{array}{l}\text { Sira } \\
\text { Rank }\end{array}$ & 1 & 3 & 4 & 2 & 1 & 2 & 3 & 4 \\
\hline
\end{tabular}

*Optimal seviyeler

*Optimal levels

Model köpüklerde yoğunluk yanıtı $\mathrm{S} / \mathrm{N}$ oranı grafiği (Şekil 1a) incelendiğinde, PASP-İ ve PASP$\mathrm{K}$ içeren köpüklerin onbeş dakika süresince yapilarina daha fazla hava katabildikleri belirlenmiş̧ir. Model koşullarında, D-PASP ve $\mathrm{Na}-\mathrm{KAZ}$ proteinlerinin arayüzey aktivitelerinin daha zayıf olduğu söylenebilmektedir. Bu durumun; D-PASP için protein içeriğinin (\%7.4) diğer proteinlerden daha düşük olmasından, $\mathrm{Na}$ KAZ (pI=4.6) açısından ise asidik koşullara duyarlı olmasindan kaynaklandığı düşünülmektedir. Na-KAZ'ın (\%0.1) ortamdaki KG veya ksantan gamla etkileşmesi neticesinde ( $\mathrm{pH} 4$, protein:gam=10:1) köpürme özelliklerinde azalma gözlendiği bildirilmiştir Bunun nedeninin sodyum kazeinatın pH 4'de çözünürlüğünün zayıf olmasından kaynaklandığı belirtilmiştir (Walsh vd., 2008).

Model köpüklerde protein:gam oranının azalmasına bağlı olarak yoğunluk yanıtı $\mathrm{S} / \mathrm{N}$ oranlarının azaldığı saptanmıştır (Şekil 1a). Model köpüklerde gam konsantrasyonunun artmasina bağlı olarak köpük üretmek için gerekli mekanik enerji artmaktadır. Çırpıcı hızının 158 rpm'de sabit tutulduğu bu çalışmada ortam viskozitesinin artmasına bağlı olarak köpük yapisına daha az havanın hapsedilebileceği tespit edilmiştir. Ksantan gam ilavesi model köpüklerin yoğunluklarını olumsuz etkilemiştir (Şekil 1a). Ksantan gamın aynı konsantrasyondaki diğer hidrokolloidlere göre çözelti viskozitesini daha fazla artırdığ1 bildirilmiştir (Barcelos vd., 2020).
Pektin kullanımıyla daha düşük yoğunlarda köpükler üretilebilmektedir.

Model köpüklerde protein oranının artmasıyla yoğunluk yanıtı $\mathrm{S} / \mathrm{N}$ oranlarının arttı̆̆ görülmektedir. Pozitif yüklü protein ve negatif yüklü polisakkaritler arasındaki etkileşimler neticesinde oluşan çözünür bileşiklerin köpük özelliklerini iyileştirdiği tespit edilmiştir (Benichou vd., 2007; Dickinson, 1998; C.K. Lau ve Dickinson, 2005; Sadahira vd., 2014).

Düşük sıcaklıklardaki kısmi denatürasyon işleminin PS proteinlerinin hidrofobik özelliklerini artırarak hava/su arayüzeyine konumlanmaları için gerekli enerji gereksinimini azalttı̆̆ bildirilmiştir (Indrawati vd., 2008; Kim vd., 2005). Bununla birlikte, PS proteinlerinin 80 oC'nin üzerine 1sitılması sonucunda köpürme özelliklerinin olumsuz etkilendiği de belirtilmiştir (Kim vd., 2005; Schmidt vd., 1984). Bu çalışmada, model köpüklerin çırpılması esnasında uygulunan sicaklık artışına bağlı olarak (80 ${ }^{\circ}$ C'ye kadar) köpüklerdeki hava oranının arttı̆̆ belirlenmiştir. Yüksek sıcaklıkta $\left(>80^{\circ} \mathrm{C}\right)$ çırpılan köpüklerde proteinlerin hava/siv1 arayüzey etkinliklerinin belirgin şekilde azaldığ sonucuna ulaşılabilmektedir. Ayrıca, model köpüklerde 100 ${ }^{0} \mathrm{C}$ 'de belirlenen yoğunluk yanıtı $\mathrm{S} / \mathrm{N}$ oranlarının $40{ }^{\circ} \mathrm{C}$ ve $60{ }^{\circ} \mathrm{C}^{\prime}$ dekinlerden yüksek bulunduğu görülmektedir. Bunun nedeni, saponinlerin PS proteinleriyle etkileşerek onların isıl dirençlerini arturmas1 (Guclu-Ustundag ve Mazza, 2007), 
ve/veya yüksek sıcakliklarda köpük oluşumunda daha etkin görev almasından kaynaklandığ1 düşünülmektedir. $\mathrm{Bu}$ bağlamda, köpük oluşumunun hedeflendiği mikrobiyolojik güvenirliliği önem arzeden ve yüksek sicaklık uygulamalar1 gerektiren g1da ürünlerinin (krem şanti, pasta dolguları, vb.) imalatında PS proteinleri ve/veya çöven suyunun kullanılabileceği düşünülmektedir.
Yoğunluk yanıtı S/N oranlanı ANOVA verileri incelendiğinde, protein çeşidinin (A) model köpüklerin yoğunluklanı üzerine etkisi istatistiksel olarak önemli bulunmuştur $(P<0.05)$. Daha az yoğun model köpüklerin üretilmesinde protein tipinin ve çırpma sıcaklı̆̆ının etki yüzdeleri sırasıyla 84.13 ve 6.04 belirlenmiştir. Polisakkarit tipinin yoğunluk yanıtı $\mathrm{S} / \mathrm{N}$ oranları üzerindeki etki oranı $\% 1.41$ ile en düşük bulunmuştur.

Çizelge 4. Model köpüklerde/köpük helvalarda yoğunluk ve renk yanıtları S/N oranları ANOVA tablosu

Table 4. ANOV A table for $S / N$ ratio of density and colour responses in model foams/foam halvas

\begin{tabular}{|c|c|c|c|c|c|c|c|}
\hline $\begin{array}{l}\text { Yanitlar } \\
\text { Responses }\end{array}$ & $\begin{array}{c}\text { Faktörler } \\
\text { Factors }\end{array}$ & $\begin{array}{c}\text { Serbestlik } \\
\text { derecesi } \\
\text { Degree of } \\
\text { freedom }\end{array}$ & $\begin{array}{l}\text { Kareler } \\
\text { toplam1 } \\
\text { Sum of } \\
\text { squares }\end{array}$ & $\begin{array}{c}\text { Kareler } \\
\text { ortalamas1 } \\
\text { Mean of } \\
\text { squares }\end{array}$ & $\begin{array}{c}\mathrm{F} \\
\text { değeri } \\
F \\
\text { value } \\
\end{array}$ & $\begin{array}{c}p \\
\text { değeri } \\
p \\
\text { value }\end{array}$ & $\begin{array}{c}\text { Katk1 } \\
\text { oran1 }(\%) \\
\text { Contribution } \\
\text { rate }(\%)\end{array}$ \\
\hline \multirow{6}{*}{$\begin{array}{l}\text { Yoğunluk } \\
\text { Density }\end{array}$} & A & 3 & 281.4 & 93.79 & 15.88 & 0.024 & 84.13 \\
\hline & B & 3 & 10.50 & 3.501 & 0.59 & 0.661 & 3.14 \\
\hline & C & 3 & 4.71 & 1.569 & 0.27 & 0.847 & 1.41 \\
\hline & $\mathrm{D}$ & 3 & 20.22 & 6.740 & 1.14 & 0.458 & 6.04 \\
\hline & $\begin{array}{l}\text { Hata } \\
\text { Error }\end{array}$ & 3 & 17.71 & 5.905 & & & 5.29 \\
\hline & $\begin{array}{c}\text { Toplam } \\
\text { Total }\end{array}$ & 15 & 334.5 & & & & 100 \\
\hline \multirow{6}{*}{$\begin{array}{l}\text { Renk } \\
\text { Colour }\end{array}$} & $\bar{A}$ & 3 & 19.83 & 6.61 & 48.48 & 0.01 & 93.36 \\
\hline & B & 3 & 0.41 & 0.14 & 1.00 & 0.50 & 1.93 \\
\hline & C & 3 & 0.30 & 0.10 & 0.74 & 0.60 & 1.41 \\
\hline & $\mathrm{D}$ & 3 & 0.28 & 0.09 & 0.69 & 0.62 & 1.32 \\
\hline & $\begin{array}{l}\text { Hata } \\
\text { Error }\end{array}$ & 3 & 0.41 & 0.13 & & & 1.93 \\
\hline & $\begin{array}{c}\text { Toplam } \\
\text { Total }\end{array}$ & 15 & 21.24 & & & & \\
\hline
\end{tabular}

PASP-İ (\%0.5), saponin (\%0.096) ve pektin (\%0.05) içeren şekerli sıvı karışımın $80^{\circ} \mathrm{C}^{\prime} \mathrm{de}$ onbeş dakika çırpılmasıyla üretilen optimum formülasyondaki köpügün yoğunluk yanıtı $\mathrm{S} / \mathrm{N}$ oranının (13.98a dB) aynı sürede çırpılan kontrol örneğinden $(11.49 \mathrm{~b} \mathrm{~dB})$ daha yüksek olduğu, aralarında istatiksel olarak anlamlı fark bulunduğu belirlenmiştir $(P<0.05)$.

Model köpük helvalarda renk yanıtının optimizasyonu: Model köpük helva örneklerinin renk ölçüm sonuçları ve $\mathrm{S} / \mathrm{N}$ değerleri Çizelge 2'de görülmektedir. Daha parlak renkte köpük helvaların üretilmesinin hedeflendiği bu araştırmada renk yanıtı $\mathrm{S} / \mathrm{N}$ değerleri 38.90-39.22 $\mathrm{dB}$ aralığında bulunmuştur. $\mathrm{L}_{16}$ tasarım matrisine göre üretilen köpük helvaların $L^{*}$ değerlerinin protein çeşidi (A) ve gam konsantrasyonundaki (B) değişimlerden daha çok etkilendiği belirlenmiştir. Model koşullarında, renk yanıtı üzerine etkisi en düşük bulunan üretim faktörünün çırpma sıcaklı̆̆1 olduğu belirlenmiştir (Çizelge 3).

Köpük helvanın rengi için model parametre seviyeleri incelendiğinde, $\% 0.5$ PASP-İ, saponin $(\% 0.096)$ ve $\% 0.1$ ksantan gam bulunduran karışımın $40{ }^{\circ} \mathrm{C}^{\prime}$ de onbeş dakika çırpılmasıyla L* 
değeri en yüksek köpük helvaların üretilebileceği belirlenmiştir $\left(\mathrm{A}_{2} \mathrm{~B}_{2} \mathrm{C}_{4} \mathrm{D}_{1}\right)$ (Çizelge 3). Optimum koşullarda üretilen köpük helva örneğinin görüntüsü Şekil 1b’de verilmiştir.

PASP-K ve PASP-I kullanılarak üretilen köpük helvaların D-PASP ve Na-KAZ'lı helvalara göre daha parlak renkte oldukları saptanmıştır Yapilan çalışmalarda protein köpüklerinin renkleri ve köpürebilme özellikleri arasında ilişki olduğu bildirilmiştir (Campbell ve Mougeot, 1999). Bu çalışmada, on beş dakikalık sürede yapısına daha fazla hava hapsedebilen örneklerin daha parlak oldukları belirlenmiştir.

\%0.1 konsantrasyona kadar ksantan gam veya pektin kullanımının renk gelişiminde etkili olduğu tespit edilmiştir (Şekil 1b). Protein köpüklerinde iyonik özellikteki gam konsantrasyonu çözünür/çözünmez bileşiklerin oluşumunda önem taşımaktadır. Bu konuda yapılan bir çalışmada, $\beta$-laktaglobulin:pektin oranı $6: 1$ oluncaya kadar pektin ilavesiyle köpük özelliklerini iyileştiren çözünür bileşenlerin oluştuğu, protein içeriğinin azalmasıyla birlikte yüzey özellikleri zayıf çözünmeyen bileşenlerin meydana geldiği tespit edilmiştir (Ganzevles vd., 2006). Bu çalışmada da, gam oranının artmasıyla (protein:gam<5) yüzey aktiviteleri zayıf çözünmez bileşenlerin oluşumuna bağlı olarak yapıya yeteri kadar hava hapsedilemediğinden $L^{*}$ değerinin düşük bulunduğu sonucuna ulaşllabilmektedir.

Model köpük helvaların üretiminde çırpma işlemi esnasinda uygulanan sicaklik derecesinin artması renk yanıtı $\mathrm{S} / \mathrm{N}$ oranlarının azalmasıyla sonuçlanmıştır (Şekil 1b). Yüksek şeker içerikli ortamda, çırpma işlemi süresince uygulanan sıcaklığın artmasıyla indirgen şeker ve proteinler arasındaki etkileşimlerin sonucunda ortaya çıkan Maillard reaksiyon ürünleri nedeniyle ürün parlaklığının azaldığ1 görülmüştür (Gharbi ve Labbafi, 2019). Bununla birlikte, PS proteinlerine denatürasyon sıcaklığının üzerinde $\left(>70 \quad{ }^{\circ} \mathrm{C}\right)$ uygulanan sicaklık işlemleri neticesinde proteinlerin arayüzey aktivitelerinin azalması da rengi olumsuz etkilemektedir.
Model köpük helvaların L* değerleri $\mathrm{S} / \mathrm{N}$ oranları ANOVA tablosuna göre, üretim parametrelerinden protein çeşidinin örneklerin parlaklıklarına \%93.36 oranında katk1 sağladığ belirlenmiştir. Diğer üretim parametrelerine ait $\mathrm{S} / \mathrm{N}$ oranlarının helvaların renk özelliğine etki oranları toplamı $\% 5$ 'in altında bulunmuştur (Çizelge 4).

$\% 0.5$ PASP-İ, \%0.096 saponin ve $\% 0.1$ ksantan gam kullanılarak hazırlanan şekerli (70 ${ }^{\circ}$ Briks) ve asitli ( $\mathrm{pH}$ 4) çözeltinin $40{ }^{\circ} \mathrm{C}$ 'de çırpılmasıyla üretilen optimum köpük helva ve geleneksel yöntemle üretilen kontrol helvanın renk ölçüm sonuçları $\mathrm{S} / \mathrm{N}$ oranları sırasıly $39.23^{a}$ ve $39.24^{a}$ $\mathrm{dB}$ hesaplanmış olup, aralarında istatistiksel olarak bir fark bulunmamıştır $(P>0.05)$.

\section{SONUÇ}

Gıda köpüklerinin üretilmesinde farklı kaynaklara ihtiyaç duyulmaktadır. Bu amaçla süt proteinlerinin kullanılabileceği çeşitli araștırmalarla ortaya konulmuştur. Bu proteinlerin belirli koşullarda iyonik özellikteki gamlarla etkileşime girmesiyle köpürme özellikleri iyileşebilmektedir. Ayrıca saponinlerin de proteinlerin köpürme özelliklerini etkiledikleri bilinmektedir. Bu çalışmada; çöven suyu, süt proteinleri ve farklı konsantrasyonlardaki gamlarla hazırlanan şekerli $(70$ oBriks) ve asitli $(\mathrm{pH} 4)$ sivinin $40{ }^{\circ} \mathrm{C}, 60{ }^{\circ} \mathrm{C}, 80^{\circ} \mathrm{C}$ veya $100{ }^{\circ} \mathrm{C}$ 'de çırpılmasıyla üretilen model köpüklerin yoğunluklarının ve model köpük helvaların renklerinin optimize edilmesinde Taguchi yöntemi kullanılmıştır. \%0.5 peynir altı suyu protein izolat1, $\% 0.096$ saponin ve $\% 0.05$ pektin kullanılarak hazırlanan sıvı karışımın $80{ }^{\circ} \mathrm{C}$ 'de onbeş dakika çırpılmasıyla üretilen optimum köpük örneğinin geleneksel yöntemle üretilenden daha iyi köpürebildiği sonucuna ulaşılmıştır. \%0.5 peynir altı suyu protein izolat1, $\% 0.096$ saponin ve $\% 0.1$ ksantan içeren çözeltinin $40 \quad{ }^{\circ}$ C'de çırpılmasıyla üretilen model köpük helva ve $\% 0.192$ saponin kullanılan kontrol örneğinin parlaklıkları arasında fark bulunmamıştır. Taguchi yöntemiyle optimize edilen yoğunluk ve renk yanıtları dikkate alındı̆̆ında, şeker içeren (70 oBriks) asitlendirilmiş ( $\mathrm{pH}$ 4) ortamda yüksek protein içeriğine sahip ticari peynir altı suyu 
protein tozlarının ticari pektin veya ksantan gam ile belli oranlarda kullanılmasıly köpük helva formülasyonundaki saponin miktarının yarı yarıya azaltılabileceği belirlenmiştir.

\section{TEŞEKKÜR}

$\mathrm{Bu}$ çalışmanın gerçekleştirilmesinde katkıları bulunan Erciyes Üniv. Gıda Müh. Bölüm Başkanlığı, Tokat Gaziosmanpaşa Üniv. Gıda Müh. Bölüm Başkanlığına ve Taguchi modelleme konusundaki yardımlarından dolayı Doç. Dr. Ercan Şenyiğit'e teşekkür ederiz.

\section{ÇIKAR ÇATISMASI BEYANI}

$\mathrm{Bu}$ makalede yazarların, diğer kişilerin ve kurumların arasında bir çıkar çatısması yoktur.

\section{YAZAR KATKILARI}

Tüm yazarlar makalenin yapilmasinda, yazılmasında ve yayınlanmasında eşit katk1 sağlamışlardır. Yazarlar makalenin son halini okumuş ve onaylamıstır.

\section{KAYNAKLAR}

Abascal, D.M., ve Gracia-Fadrique, J. (2009). Surface tension and foam stability of commercial calcium and sodium caseinates. Food Hydrocolloids, 23(7): 1848-1852.

Abd El-Salam, M.H., ve El-Shibiny, S. (2020). Preparation and potential applications of caseinpolysaccharide conjugates: a review. Journal of the Science of Food and Agriculture, 100(5): 1852-1859.

Albano, K.M., Cavallieri, Â.L.F., ve Nicoletti, V.R. (2019). Electrostatic interaction between proteins and polysaccharides: Physicochemical aspects and applications in emulsion stabilization. Food Reviews International, 35(1): 54-89, https://doi.org/10.1080/87559129.2018.146744 2.

Anonim, (2015). Türk Gıda Kodeksi Tahin Helvası Tebliği (Tebliğ No:2015/28). Tarm ve Köyişleri Bakanliğg, Ankara.

Barcelos, M.C.S., Vespermann, K.A.C., Pelissari, F.M., ve Molina, G. (2020). Current status of biotechnological production and applications of microbial exopolysaccharides. Critical Reviews in Food Science and Nutrition, 60(9): 1475-1495, https://doi.org/10.1080/10408398.2019.157579 1.

Battal. H., Sarı. F., ve Velioğlu. S. (2003). Çöven Ekstraktı Üretimi Üzerine Bir Araştırma. Anadolu Üniversitesi Bilim ve Teknoloji Dergisi, 4(1): 75-84.

Benichou, A., Aserin, A., Lutz, R., ve Garti, N. (2007). Formation and characterization of amphiphilic conjugates of whey protein isolate (WPI)/xanthan to improve surface activity. Food Hydrocolloids, 21(3): 379-391.

Böttcher, S., Scampicchio, M., ve Drusch, S. (2016). Mixtures of saponins and betalactoglobulin differ from classical protein/surfactant-systems at the air-water interface. Colloids and Surfaces A: Physicochem. Eng. Aspects, 506: 765-773.

Çam, İ.B., ve Topuz, A. (2018). Production of soapwort concentrate and soapwort powder and their use in Turkish delight and tahini halvah. $J$ Food Process Eng., 41(1): 1-8.

Campbell, G.M., ve Mougeot, E. (1999). Creation and characterisation of aerated food products. Trends in Food Science and Technology, 10(9): 283-296.

Çelik, I., Yilmaz, Y., Işik, F., ve Üstün, Ö. (2007). Effect of soapwort extract on physical and sensory properties of sponge cakes and rheological properties of sponge cake batters. Food Chemistry, 101(3): 907-911.

Dickinson, E. (1998). Stability and rheological implications of electrostatic milk proteinpolysaccharide interactions. Trends in Food Science \& Technology, 9(10): 347-354.

Foegeding, E.A., Luck, P.J., ve Davis, J.P. (2006). Factors determining the physical properties of protein foams. Food Hydrocolloids, 20(2-3): 284292.

Ganzevles, R.A., Zinoviadou, K., Van Vliet, T., Stuart, M.A.C., ve De Jongh, H.H.J. (2006). Modulating surface rheology by electrostatic protein/polysaccharide interactions. Langmuir, 22(24): 10089-10096.

Gharbi, N., ve Labbafi, M. (2018). Effect of processing on aggregation mechanism of egg white proteins. Food Chemistry, 252: 126-133. 
Girard, M., Turgeon, S.L., ve Gauthier, S.F. (2003). Quantification of the interactions between $\beta$-lactoglobulin and pectin through capillary electrophoresis analysis. Journal of Agricultural and Food Chemistry, 51(20): 6043-6049.

Guclu-Ustundag, Ö., ve Mazza, G. (2007). Saponins: Properties, applications and processing. Critical Reviews in Food Science and Nutrition, 47(3): 231-258.

Ibanoglu, E., ve Erçelebi, E.A. (2007). Thermal denaturation and functional properties of egg proteins in the presence of hydrocolloid gums. Food Chemistry, 101(2): 626-633.

Indrawati, L., Wang, Z., Narsimhan, G., ve Gonzalez, J. (2008). Effect of processing parameters on foam formation using a continuous system with a mechanical whipper. Journal of Food Engineering, 88(1): 65-74.

Kim, D.A., Cornec, M., ve Narsimhan, G. (2005). Effect of thermal treatment on interfacial properties of $\beta$-lactoglobulin. Journal of Colloid and Interface Science, 285(1): 100-109.

Lau, C.K., ve Dickinson, E. (2005). Instability and structural change in an aerated system containing egg albumen and invert sugar. Food Hydrocolloids, 19(1): 111-121.

Lazidis, A., Hancocks, R.D., Spyropoulos, F., Kreuß, M., Berrocal, R., ve Norton, I.T. (2014). Whey protein fluid gels for the stabilisation of foams. Food Hydrocolloids, 53:209-217.

Liszka-Skoczylas, M., Ptaszek, A., ve Zmudziński, D. (2014). The effect of hydrocolloids on producing stable foams based on the whey protein concentrate (WPC). Journal of Food Engineering, 129: 1-11.

Martínez-Padilla, L.P., García-Rivera, J.L., Romero-Arreola, V., Casas-Alencáster, N.B. (2015). Effects of xanthan gum rheology on the foaming properties of whey protein concentrate. Journal of Food Engineering, 156: (22-30).

Mekonnen, T.H., Mussone, P.G., Choi, P., ve Bressler, D.C. (2015). Development of Proteinaceous Plywood Adhesive and Optimization of Its Lap Shear Strength.
Macromolecular Materials and Enginering, 300(2): 198209, https://doi.org/10.1002/mame.201400199

Narchi, I., Vial, C., ve Djelveh, G. (2009). Effect of protein-polysaccharide mixtures on the continuous manufacturing of foamed food products. Food Hydrocolloids, 23(1): 188-201.

Neves, I.C.O., de Faria, J.T., Vidigal, M.C.T.R., Fidelis, P.C., Minim, V.P.R., ve Minim, L.A. (2018). Foaming properties of suspensions composed by $\beta$-lactoglobulin and polysaccharides, in the presence of sucrose or polyols. Colloids and Surfaces A: Physicochemical and Engineering Aspects, 550: 199-208, https://doi.org/10.1016/j.colsurfa.2018.04.039.

Özakın, A.N., ve Kaya, F. (2020). Optimization of Control Parameters Affecting Panel Surface Temperature in Air-Cooled PVT Panels. Journal of the Institute of Science and Technology, 10(1): 509-519.

Pernell, C.W., Foegeding, E.A., Luck, P.J., ve Davis, J.P. (2002). Properties of whey and egg white protein foams. Colloids and Surfaces A: Physicochemical and Engineering Aspects, 204(1): 9-21.

Ravanfar, R., Tamadon, A.M., ve Niakousari, M. (2015). Optimization of ultrasound assisted extraction of anthocyanins from red cabbage using Taguchi design method, 52: 8140-8147.

Roy, R.K. (2010). A Primer on the Taguchi method. 2nd Edition, Michigan: Society of Manufacturing Engineers, USA, 299 p.

Sadahira, M.S., Lopes, F.C.R., Rodrigues, M.I., Netto, F.M. (2014). Influence of protein-pectin electrostatic interaction on the foam stability mechanism. Carbohydrate Polymers, 103(1): 55-61, http://dx.doi.org/10.1016/j.carbpol.2013.11.070

Sarıçoban, C., Karakaya, M. (2004). Geleneksel gıdalardan köpük helvanın endüstriyel ölçekte üretimi. Geleneksel Gidalar Semposyumu, 23-24 Eylül, Van, Türkiye, 104-105s.

Schmidt, R.H., Packard, V.S., ve Morris, H.A. (1984). Effect of Processing on Whey Protein Functionality. Journal of Dairy Science, 67(11): 27232733. 
Shen, X., Shao, S., ve Guo, M. (2017). Ultrasound-induced changes in physical and functional properties of whey proteins. International Journal of Food Science \& Technology, 52(2): 381-388.

Silva, M.B., Carneiro, L.M., Silva, J.P.A., Dos Santos Oliveira, I., Filho, H.J.I., Oliveira Almeida, C.R. (2014). An Application of the Taguchi Method (Robust Design) to Environmental Engineering: Evaluating Advanced Oxidative Processes in Polyester-Resin Wastewater Treatment. American Joumal of Analytical Chemistry, 5(13): 828-837.
Ulaganathan, V., Del Castillo, L., Webber, J.L., Ho, T.T.M., Ferri, J.K., Krasowska, M., ve Beattie, D.A. (2019). The influence of $\mathrm{pH}$ on the interfacial behaviour of Quillaja bark saponin at the air-solution interface. Colloids and Surfaces B: Biointerfaces, 176: 412-419.

Walsh, D.J., Russell, K., ve FitzGerald, R.J. (2008). Stabilisation of sodium caseinate hydrolysate foams. Food Research International, 41(1): 43-52, https://doi.org/10.1016/ j.foodres.2007.09.003. 